\title{
Ecosystem Restoration Policy and Implementation in Production Forest in Indonesia
}

\author{
Maria Helena Yeni Pareira ${ }^{1 *}$, Hariadi Kartodihardjo ${ }^{2}$, Bahruni $^{2}$ \\ 'Graduate Program of Forest Management Science, Faculty of Forestry and Environment, IPB University, Academic Ring \\ Road, Campus IPB Dramaga, Bogor, Indonesia 16680 \\ ${ }^{2}$ Department of Forest Management, Faculty of Forestry and Environment, IPB University, Academic Ring Road, Campus IPB \\ Dramaga, Bogor, Indonesia 16680
}

\author{
Received January 13, 2020/Accepted September 17, 2020
}

\begin{abstract}
The issuance of the Ministry of Forestry Regulation (Number SK 159/Menhut-II/2004) on Ecosystem Restoration in Production Forest marked a paradigm shift in production forest management in Indonesia from timber to ecosystembased. By 2019, the Ministry of Environment and Forestry (MoEF) has issued 16 ecosystem restoration concessions (ERC) in production forest totaling 622,826 ha, or only $21 \%$ out of the 3 million ha of MoEF's target. Although this policy was considered a breakthrough and it garnered significant attention, currently, there is no comprehensive assessment on the development of ERC policy and its impacts on achieving MoEF's target. Applied a combination of policy content, process, and implementation analysis, and rational policy analysis, this research examined the gaps in ER policy and implementation and identified policy space to pursue necessary policy improvement. The findings suggested that existing policy remains inadequate to support the implementation of ERC from the licensing process to performance evaluation. This study has identified the need to revise the applicable regulations to facilitate the objectives of ERC management unit, and the objective of ecosystem restoration in the production forest. Revisions include ecological, social, and economic aspects using available policy space that supported by the coalition of actors within the Ecosystem Restoration Working Group.
\end{abstract}

Keywords: ecosystem restoration, production forest, policy process, policy space

*Correspondence author, email:jenipareira@gmail.com

\section{Introduction}

Since the beginning of the New Order regime in 1968, the forestry business, particularly timber, has been the main pillar for Indonesia's economic development. This lucrative business developed rapidly until the end of the 1990s. The long history of forest utilization in Indonesia has led to the degradation of the production forest due to the unsustainable utilization of forests. Many logging concessions in the natural forest have ceased their operation due to a combination of different factors including unhealthy financial condition, lack of human resources capacity, lack of the commitment to the sustainable forest production, high production and transaction costs, decreasing forest potential in both quality and quantity, uncompetitive timber price, and social conflict (Center of Forestry Planning and Statistic, 2009; Purba et al., 2014).

In 1993, 575 logging concessions were operating in Indonesia, covering a total area of up to 61.7 million ha. Since then, the number of logging concessions operating in Indonesia had decreased significantly to 323 units covering a total area of 28.8 million ha in 2007 (Center of Forestry Planning and Statistic, 2009). These numbers continued to decrease to 277 units in 2013, and in 2017 only 259 units were still in operation with a total area of 18.8 million ha or only $29.7 \%$ from the total logging concession area in 1993 (MoEF, 2017).

Unsustainable forest utilization has led to deforestation and severe degradation of Indonesia's production forest. In $2009,77 \%$ of the production forest in Sumatera and Kalimantan was deforested. Between 2009-2013 Indonesia lost 1.28 million ha of natural forest cover in production forest and 0.7 million ha in the limited production forest (Purba et al., 2014). The same report also revealed that in 2013 , out of the 20.5 million ha of logging concession, only $54 \%$ remains as natural forest, while in the industrial forest plantation area, only $15 \%$ remains as natural forest, out of the total 10 million ha.

The production of the log from the production forest in Sumatera and Kalimantan has decreased significantly from 176.3 million $\mathrm{m}^{3}$ in 1994 to 5.6 million $\mathrm{m}^{3}$ in 2006 (Center of Forestry Planning and Statistic, 2009). At the national level, the production of Indonesia's $\log$ is 89 million $\mathrm{m}^{3}$ year ${ }^{-1}$ from natural forest and 3-4 million $\mathrm{m}^{3}$ from industrial forest plantation, far below from the 60 million $\mathrm{m}^{3}$ of industrial $\log$ demand. These gaps were filled by illegal logging and from forest conversion into other purposes (World Bank, 2006). 
The BPS (2016) data showed that the production of the $\log$ from all logging concessions in Indonesia in 2006 was 8.5 million $\mathrm{m}^{3}$ and continued to decrease to 5.8 million $\mathrm{m}^{3}$ in 2015. In 2017, the production of the $\log$ from the natural forest was only 3.9 million $\mathrm{m}^{3}$ (Directorate General of Sustainable Production Forest Management, 2017).

Despite the inconsistencies found in the national log production data, these figures clearly indicate that production forest in Indonesia has been heavily destructed and deforested, thereby restoring the biotic and abiotic elements of the production forest to reach its ecological balance, or known as ecosystem restoration, is imperative (MoF, 2004). Margono et al. (2012) research revealed that intensive forest clearing has resulted in the conversion of $70 \%$ of Sumatera's forest areas up to 2010 with the highest rates of forest loss in the production forest. Meanwhile, Gaveau et al. (2013) research revealed that between 2000 to 2010, Kalimantan loss $25 \%$ of its production forest. Tsujino et al. (2016) research on the history of forest loss and degradation in Indonesia revealed that forest logging concessions were one of the most drivers of the forest lost in Indonesia, driven by international demand for wood and pulp.

Considering the state of Indonesia's production forest, in 2004, the Ministry of Forestry issued Regulation Number SK.159/Menhut-II/2004 on the ecosystem restoration in the production forest. This regulation is a policy direction that considered as a breakthrough in the management of the production forest in Indonesia. This regulation was considered as the foundation for a paradigm shift, where the production forest is seen not merely for timber extraction purposes but also to produce multi-products through ecosystem-based management (Silalahi \& Erwin, 2016). Since 2004, the Government of Indonesia (GoI) has issued many regulations to facilitate the implementation of ecosystem restoration concessions (ERC) in Indonesia.

As a breakthrough regulation, ecosystem restoration garnered interest from various stakeholders such as NGOs, the private sector, and the scientific community. However, scientific literature and researches related to the ERC are still limited. Researches associated with ERC including the business feasibility of ERC (Rahmawati, 2013), the role of ERC in the preservation of high-conservation value wildlife (Sitompul et al., 2011), the impact of ERC on forest and conflict that occurred between forest-dependent communities (Silalahi \& Erwin, 2015; Buergin, 2016), and land use, income and ethnic diversity in the margin of Hutan Harapan in Jambi, and South Sumatera Provinces (Widianingsih et al. 2019). A comprehensive analysis of the development of ecosystem restoration policy at the national level and its impact on supporting the achievement of Indonesia's ecosystem restoration target was not yet available.

Although the concept of ecosystem restoration in the production forest in Indonesia was just introduced in the 2000 s, the ecosystem restoration concept is not entirely new. It is rooted in Aldo Leopold's work on ecological restoration in the 1930s, which laid a foundation for the establishment of the Society for Ecological Restoration (SER) in 1987
(Covington et al. 1999). SER then defined ecological restoration as the process of re-establishing to the extent of possible the structure, function, and integrity of indigenous ecosystems and sustain habitats that they provide (Covington et al., 1999). The Convention on Biological Diversity (CBD) (2016) identified restoration as the contribution to reversing the loss of biodiversity, recovering connectivity and improving ecosystem resilience, enhancing the provision of ecosystem services, combating the effect of land degradation and climate change, as well as improving human wellbeing; while reducing environmental risk and scarcity. Thereby, ecosystem restoration has two specific roles; those are contributing to the goals of biodiversity conservation and generating benefits for human wellbeing (Gann et al., 2019).

In 2010, Ministry of Environment and Forestry (MoEF) had set a target to restore 2.5 million ha of production forest between 2010 to 2014 (MoF, 2010) and an additional 500,000 ha by 2019 (MoEF, 2015). Up to 2019, MoEF has received 72 ERC applications (MoEF, 2018) ${ }^{1}$ and issued 16 ERC permits covering a total area of 622,826 ha of production forest. Therefore, the total production forest under ERC is only $21 \%$ of the MoEF ecosystem restoration target (Table 1).

These facts indicate that although ecosystem restoration in the production forest is perceived as a solution to restore the Indonesian production forest, which has been degraded and deforested, there are remain many challenges to implement this concept. Buergin (2016) state there are weaknesses and dispute in the legal framework for ERC. High investment and operational cost, as well as uncertainty on the long-term financing for ERC, is another challenge in the implementation of ERC (Silalahi \& Utomo, 2014; Buergin 2016). Brancalion et al. (2019) research revealed that limited funding is a major barrier to implementing ambitious global restoration commitments, thereby reducing restoration cost and provision of financial incentives to ER actors are essential to upscale restoration.

Considering those facts, this research has three objectives: a) to analyze the content of ERC regulations and the gap in the implementation of the regulations; b) to understand actor's rational choices in pursuing or implementing ERC; and c) to identify available policy space to pursue necessary ERC policy improvements.

\section{Methods}

This research was carried out from June 2018 to July 2019. Data and information were collected through literature review, participatory observation, and in-depth interviews with key informants. Purposive sampling method was applied to select key informants combined with snowballing sampling techniques (Nadefier et al., 2017). A set of criteria was applied to select informants for the research:

1. ERC applicant

2. ERC permit holder

3. MoEF staffs who are in charge of developing policy and/or implementation of ERC in Indonesia.

4. Experts and/or practitioners who are involved in the implementation of ERC or considered to have influence 
in the development of ERC policy and its implementation in Indonesia.

The data were analyzed by using descriptive qualitative method. This research applied qualitative policy content analysis (Hsieh \& Shannon, 2005; Howland et al. 2006; Hall $\&$ Steiner, 2020) and rational policy analysis of ecosystem restoration actors (Arts, 2012) and the policy process analysis developed by Institute of Development Studies (IDS) (2006). This research analyzed the content of ERCrelated regulation issued by the GoI from 2004 to 2019 in providing direction for implementing ERC and addressing challenges encountered in the implementation of ERC in Indonesia.

Following IDS's (2006) simple framework, this research analyzed ERC policy process by examining linked between three interconnected themes include a) knowledge and discourse that define what the policy narrative proposed by different actors and how is it framed, b) actors and network (who is involved and how they are connected), and c) politics and interest (what are the underlying power dynamics). By understanding these three themes enable this research to identify available policy space (IDS, 2006; Sutton, 1999), if policy revision on ERC is considered necessary; and to forecast the future of ecosystem restoration policy in the production forest in Indonesia (Dunn, 2013).

\section{Results and Discussion}

ERC progress in Indonesia Ecosystem restoration in the production forest was formally introduced in 2004 through the issuance of the Ministry of Forestry Regulation Number 159/Menhut-II/2004. This minister regulation was considered a policy discretion since the higher regulation on ERC did not exist. The legal basis of ecosystem restoration in the production forest in Indonesia was issued in 2016 through Government Regulation Number 6/2007. This regulation introduced the term timber utilization permit for ecosystem restoration (herein and after is referred to as "ERC-Ecosystem Restoration Concession"). GoI's commitment to supporting the implementation of ERC in Indonesia was demonstrated through the issuance of over 30 regulations from 2004 to 2019, which directly and indirectly govern ecosystem restoration in the production forest. It includes 2 government regulations, 28 minister of environment and forestry regulations, and 3 regulations of director-general of sustainable production forest management.

Until 2019, MoEF has issued 16 ERC permits located in Sumatera and Kalimantan (Table 1). The total area manages by the 16 ERC management units is 622,865 ha or only $21 \%$ out of MoEF target of 2.5 million ha of ERC area between 2010-2014 (MoF, 2010) with an additional 500,000 ha target added by 2019 (MoEF, 2015).

The result of the content analysis of ERC regulations revealed incoherence in the definition of ecosystem restoration in the production forest in Indonesia ${ }^{2}$, which has led to multi interpretations by different ERC actors. How ERC is being defined directly affects its implementation on the ground. This is shown most saliently in the

Table 1 Ecosystem restoration concession in Indonesia

\begin{tabular}{|c|c|c|c|}
\hline Companies & Location (Province) & $\begin{array}{l}\text { Total area } \\
\text { (ha) }\end{array}$ & Initiator \\
\hline PT Restorasi Ekosistem Indonesia (PT REKI) & South Sumatera & 52,170 & NGO \\
\hline PT Restorasi Ekosistem Indonesia & Jambi & 46,385 & NGO \\
\hline $\begin{array}{l}\text { PT Restorasi Habitat Orangutan Indonesia } \\
\text { (PT RHOI) }\end{array}$ & East Kalimantan & 86,450 & NGO \\
\hline PT Ekosistem Khatulistiwa Lestari (PT EKL) & West Kalimantan & 14,080 & Private sector \\
\hline PT Gemilang Cipta Nusantara (PT GCN) & Riau & 20,265 & Private sector \\
\hline PT Rimba Raya Conservation (PT RRC) & Central Kalimantan & 36,954 & Private sector \\
\hline PT Sipef Biodiversity Indonesia (PT SBI) & Bengkulu & 12,656 & Private sector \\
\hline PT Rimba Makmur Utama (PT RMU) & Central Kalimantan & 108,255 & Private sector \\
\hline PT Gemilang Cipta Nusantara (PT GCN) & Riau & 20,450 & Private sector \\
\hline PT Karawang Ekawana Nugraha (PT KEN) & South Sumatera & 8,300 & Private sector \\
\hline PT Sinar Mutiara Nusantara (PT SMN) & Riau & 32,830 & Private sector \\
\hline PT Global Alam Nusantara (PT GAN) & Riau & 36,850 & Private sector \\
\hline PT The Best One Unitimber (PT TBOU) & Riau & 39,412 & Private sector \\
\hline PT Alam Bukit Tigapuluh (PT ABT) & Jambi & 38,665 & NGO \\
\hline PT Alam Sukses Lestari (PT ASL) & Central Kalimantan & 19,520 & Private sector \\
\hline PT Rimba Makmur Utama 2 & Central Kalimantan & 49,620 & Private sector \\
\hline Total area & & 622,862 & \\
\hline
\end{tabular}

${ }^{2}$ MoF Regulation Number SK.159/Menhut-II/2004, MoF Regulation Number P.18/Menhut-II/2004, and Government Regulation Number 6/2007 in lieu Government Regulation Number 3/2008 
implementation of ERC under timber utilization business permit, which had fundamental implication to the technical regulations for ERC that remains leaning heavily toward the utilization of timber. In principle, the legal interpretation of ecosystem restoration in production forest definition in Government Regulation Number 6/2007 is to restore the potential of production forest, allowing for the resumption of timber production. Thereby, the ecosystem restoration definition in the production forest needs to be revisited to guide the interpretation and implementation of the concept. This is imperative to achieve the objective of ecosystem restoration as defined by SER (Covington et al., 1999) and CBD (2016), noting the importance of restoring ecosystem function to generate benefits not only for biodiversity but also for human wellbeing.

Furthermore, the result of the content analysis and interview with the key informants revealed some aspects of the policy, includes determination of indicative areal for ERC, long licensing process through different levels of Government have resulted in delaying implementation, and high transaction costs. Thus potentially impeding the achievement of ecosystem restoration target both the total area under ERC, and the ecosystem restoration outcome, which should be assessed from the ecological, economic, and social aspect (Table 2). According to Brockhaus et al. (2012), the history of land use, planning, and allocation in Indonesia is characterized by a complex landscape of institutions and legal framework, which include multiple actors and their interest, as well as the problematic issues of efficiency, equity, and transparency. High transaction costs were found in almost the forestry business licensing process in Indonesia (Kartodihardjo et al., 2015).

Policy's narration the ecosystem restoration of the production forests The concept of ecosystem restoration in the production forest was introduced in 2000 , by a nongovernmental organization (NGO), Burung Indonesia. The concept aimed at restoring the production forest that has been heavily degraded without utilizing timber from the area under restoration. This concept will provide an opportunity for the Indonesian legal entity to focus on the conservation of biodiversity to manage the production forest in Indonesia. As a new concept, it received mixed responses. The history of production forest utilization in Indonesia heavily relied on timber was dominated by big logging companies. It was no surprise that the ER concept was initially received with skepticism since NGOs were deemed inexperienced or had no track record in managing the production forest in Indonesia.

The narrative proposed by the ERC initiator was that Indonesia's production forest had been heavily degraded due to the unsustainable harvesting of timber; therefore, restoration of the production forest is urgently required. Roe (1991) stated that policy narratives are often developed to simplify complex issues to trigger action and are often based on the weak scientific claim. However, in the case of ERC in
Indonesia, the narratives proposed was supported by strong fact and data that the production forest has been heavily destructed and deforested. The overexploitation of natural forest resources has resulted in the decrease of timber supply from the natural forest, which led to the declining in the contribution of the forestry sector to gross domestic product to less than 1\% in 2009 (Susanti \& Maryudi, 2016). The ecosystem restoration concept was considered as a potential solution to address this production forest crisis narrative. Thereby, in 2004 the MoEF issued regulation Number SK.159/Menhut-II/2004 on the Ecosystem Restoration in Production Forest.

However, during the interview ${ }^{3}$, we found that some parties still perceive ecosystem restoration on the production forest as a temporary suspension of timber extraction to restore the productivity of production forest, particularly for high economic value timber species. Improve the economic value of the production forest requires a shift of paradigm in the production forest management, from timber production orientation to more holistic management of natural production forest landscape. It could be achieved through optimizing the potential of production forest, either in the form of timber, non-timber forest products, or environmental services (Agung et al. 2018). Production forest management should be directed towards supporting the achievement of food, energy, and clean water resiliency. The narration formulation in the policy issuing process of ecosystem restoration on the production forest clearly shows overlapping and competing agendas among stakeholders, so achieving total agreement over a fundamental policy problem will be daunting if not impossible (IDS, 2006).

Ecosystem restoration actors and working group A policy process was influenced by different interest groups, which use its power and authority to affect each stage of policy processes. The interest of each actor might be accommodated through the utilization of certain narratives (IDS, 2006). This was also true in the ecosystem restoration policy process. Although MoEF has initiated the paradigm shift in the management of natural production forest through the ERC policy issuance, the content of the ecosystem restoration policies remained heavily oriented towards timber utilization. Taking into account governance with a transparent system, and public participation was still low. Moreover, the current bureaucracy system does not effectively support the implementation of $\mathrm{ERC}^{4}$. In addition, the shift of paradigm in the production forest management has not occurred at the local government level yet. Therefore many local government institutions treat ERC similarly to logging concessions, which leads to high transaction costs (Myers-Madeira et al., 2010). The implementation of ERC under timber utilization business permit that can be held only by a forest business entity partly contributed to this situation. The destruction of the production forest is the failure of forest management policy (Kartodihardjo, 2017), thereby restoration should be the responsibility of the Government. It

${ }^{3}$ Interview with a researcher at the Centre of Forestry Research and Development (on $20^{\text {th }}$ June 2019) and with the Head of Sub-directorate of Production Forest Utilization-MoEF (on $16^{\text {th }}$ July 2019)

${ }^{4}$ Interview with a scientist from IPB University, $20^{\text {th }}$ June 2019 
Table 2 Content analysis of ecosystem restoration regulations and its implementation

\begin{tabular}{|c|c|c|c|}
\hline $\begin{array}{l}\text { Aspects } \\
\text { analyzed in } \\
\text { the regulation }\end{array}$ & Regulations & Content & $\begin{array}{l}\text { The implication and the implementation of ER } \\
\text { regulations }\end{array}$ \\
\hline $\begin{array}{l}\text { Ecosystem } \\
\text { restoration } \\
\text { definition }\end{array}$ & $\begin{array}{l}\text { - MoF Regulation No. } \\
\text { SK 159/Menhut- } \\
\text { II/2004, } \\
\text { - MoF Regulation No. } \\
\text { 18/2004, } \\
\text { - } \text { GR No. } 6 / 2007\end{array}$ & $\begin{array}{l}\text { These regulations have different explanation } \\
\text { to the term of ecosystem restoration and } \\
\text { timber utilization business permit for } \\
\text { ecosystem restoration }\end{array}$ & $\begin{array}{l}\text { - Different term and explanation of ERC in these } \\
\text { regulations may lead to multi-interpretation of } \\
\text { the regulations. } \\
\text { - It will affect decision of the management unit } \\
\text { in define the objective of ERC and the } \\
\text { management intervention required to achieve } \\
\text { ecosystem balance }\end{array}$ \\
\hline $\begin{array}{l}\text { Indicative } \\
\text { area for ERC }\end{array}$ & $\begin{array}{l}\text { - MoF Regulation No. } \\
\text { 18/2004, } \\
\text { - MoEF Regulation No. } \\
\text { 28/MENLHK/SETJEN } \\
\text { KUM.1/7/2018, } \\
\text { - MoEF Decree No. } \\
\text { SK.9246/MenLHK- } \\
\text { PHPL/KPHP/HPL.0/1 } \\
\text { 2/2018 }\end{array}$ & $\begin{array}{l}\text { - Indicative areal for ERC does not overlap } \\
\text { with other permit or right, } \\
\text { - The following aspect should be take into } \\
\text { consideration in the appointment of } \\
\text { indicative areal for ERC: the change in the } \\
\text { spatial plan, recent land cover data and } \\
\text { information, input from community, result } \\
\text { of field survey and revised licensing data } \\
\text { - Areal eligible for ERC are the areal has } \\
\text { been reserved or appointed by the MoEF, } \\
\text { which serve as a reference for the Governor } \\
\text { to issue the recommendation letter. } \\
\text { - In } 2018, \text { MoEF issued an indicative map for } \\
\text { the utilization of production forest, which } \\
\text { include } \pm 1,557,520 \text { ha of production forest } \\
\text { for ERC. }\end{array}$ & $\begin{array}{l}\text { - In reality, the indicative areal for ERC was } \\
\text { appointed on the map without proper field } \\
\text { survey and input from public. } \\
\text { - Many ERCs area are overlap with other permit } \\
\text { or community claim, e.g. community's } \\
\text { agricultural land and settlement area. } \\
\text { - This situation has triggered social conflict in } \\
\text { several ERCs. In many cases, the state were } \\
\text { absent in resolving the conflict, leaving the } \\
\text { ERC management unit dealing with the } \\
\text { problem which required significant time, } \\
\text { energy and cost. }\end{array}$ \\
\hline $\begin{array}{l}\text { ERC } \\
\text { licensing } \\
\text { process }\end{array}$ & $\begin{array}{l}\text { - MoF Regulation No. } \\
\text { SK. 159/Menhut- } \\
\text { II/2004 } \\
\text { - GR No. 6/2007 } \\
\text { - MoF Regulation No. } \\
\text { P. 61/Menhut-II/2008 } \\
\text { and its amendment, } \\
\text { the last amendment is } \\
\text { No. P.19/MenLHK/ } \\
\text { SETJEN/KUM.1/ } \\
\text { 4/2019. }\end{array}$ & $\begin{array}{l}\text { The regulation on ERC licensing process and } \\
\text { permit extension has been amended for } 11 \\
\text { times, from the beginning through the bidding } \\
\text { process up to present through application } \\
\text { process via Online Single Submission Agency. } \\
\text { The regulation has clearly defined the } \\
\text { following: } \\
\text { - The ERC licensing and permit extension } \\
\text { process } \\
\text { - The cost should be borne by the applicant } \\
\text { - Licensing process might be proceed if in } 10 \\
\text { days the Governor does not issue a } \\
\text { recommendation letter. }\end{array}$ & $\begin{array}{l}\text { - In general, the ER concessioner spent 2-4 years } \\
\text { to secure the permit through a complex process } \\
\text { and in some cases include high transaction cost. } \\
\text { - A long licensing process, leaving the proposed } \\
\text { area under encroachment because irresponsible } \\
\text { parties seen that as an "open access" area. } \\
\text { - The ERCs applicant will not proceed their } \\
\text { application process without Governor } \\
\text { recommendation, because later in the } \\
\text { implementation phase, the concessioner should } \\
\text { secure local government agencies approval for } \\
\text { their annual working plan. }\end{array}$ \\
\hline $\begin{array}{l}\text { Silviculture in } \\
\text { the ERC and } \\
\text { ecosystem } \\
\text { balance }\end{array}$ & $\begin{array}{l}\text { - MoF Regulation No. } \\
\text { P.64/Menhut-II/2014 }\end{array}$ & $\begin{array}{l}\text { The application of silviculture techniques } \\
\text { before the ecosystem balance is reached and } \\
\text { silviculture system once the ecosystem } \\
\text { balance is reached. }\end{array}$ & $\begin{array}{l}\text { - This regulation did not provide specific } \\
\text { guidelines for silviculture techniques or system } \\
\text { for each ecosystem type, whereas the ERCs are } \\
\text { located in several ecosystem type such as } \\
\text { lowland tropical forest, mangrove, peatland, } \\
\text { etc. } \\
\text { - Division of the ER area into zone and block is } \\
\text { suitable for timber-based forest management. } \\
\text { However, it is considered will limit the } \\
\text { effectiveness of flora and fauna restoration. } \\
\text { Moreover, the majority of the ERC } \\
\text { management units currently operating in } \\
\text { Indonesia do not intended to extract the timber } \\
\text { within the concession } \\
\text { - Criteria and indicator of ecosystem balance } \\
\text { defined in this regulation is heavily focus on } \\
\text { ecological perspective, and did not have } \\
\text { sufficient attention to the total economic value } \\
\text { of the different function of ecosystem balance. } \\
\text { - This regulation also identified agroforestry } \\
\text { system as an option to reduce encroachment } \\
\text { and mitigate illegal activities in the ERC. } \\
\text { However, further guideline/technical } \\
\text { regulations is need to operational this } \\
\text { agroforestry system in the ERC. }\end{array}$ \\
\hline
\end{tabular}


Table 2 Content analysis of ecosystem restoration regulations and its implementation (continued)

\begin{tabular}{lcl}
\hline $\begin{array}{l}\text { Utilization of } \\
\text { other forest } \\
\text { products in }\end{array}$ & $\begin{array}{l}\text { GR No. 6/2007 in lieu } \\
\text { of GR No. 3/2008 }\end{array}$ & $\begin{array}{l}\text { ERC management unit may develop } \\
\text { multi-product business in line with the } \\
\text { condition and the potential of the area. }\end{array}$
\end{tabular}
the ERC multi-product business in line with the and the potential of the area.

Performance
evaluation of
sustainable
production
forest
management
and
verification of
timber
legality

- GR No. 6/2007 in lieu of GR No. 3/2008

- Regulation of Director General of Forestry Business No. P.4/VI/BPPHH/2014

legality
MOEF will evaluate the performance of an ERC management unit every 5 years.

- Provide standard and guideline to evaluate the performance of sustainable production forest management and verification of timber legality

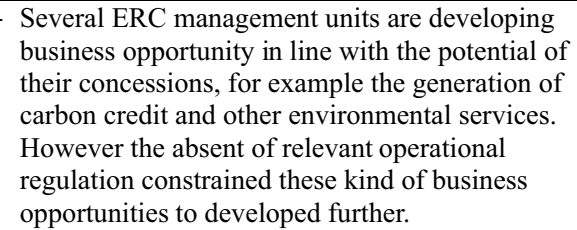
carbon credit and other environmental services. However the absent of relevant operational regulation constrained these kind of business opportunities to developed further.

- In the implementation, the performance evaluation more focus on the administrative aspect, which is the obligation of concessionaire as stated in the permit. It did not evaluated the contribution of each indicator and verifier to the achievement of management objective of each ERC management unit.

- The silviculture techniques/system define in the regulation are very general, not specific for each ecosystem type. The logical consequences is the monitoring and evaluation tool also very general thereby do not effective in evaluate the ecosystem restoration achievement for different type of ecosystem.

- The evaluation conducted have not evaluated outcomes of ER activities.

- The forest management system once the ecosystem balance is reached is more focus on the timber management. The regulations do not provide further guidance for utilization of other forest products as potential business opportunities.

- The condition of production forest that has been degraded and deforested is the result of the failure of forest management policy thereby it is government obligation to restore the production forest.

- Initial investment and operation cost of an ERC is very high. For example PT REKI spent USD 1 million annually for the operational cost. ${ }^{5}$

- Considering the two points above, the Government should consider the provision of incentives for ERC concessionaire, be it in the form of ease in the payment of license fee, land and building tax exemption, and reduction in the amount of non-state income tax for the forest products/services generate in an ERC. is paradoxical to expect the private companies to pay for the implementation of ERC that required high cost, including set-up cost, operational cost, and development cost. PT REKI estimated the operational cost of ERC in the 2016-2021 period at USD 1.7 million per annum (Davie \& Ridwansyah, 2016). Considering this, an ERC should be managed not only with an ecological perspective but also with a business perspective to ensure the sustainability of financing during the 60 years (potentially 95 years) of the ERC permit period. Davie and Ridwansyah (2016) analysis revealed that 6 ERC management units are currently dependent on donor funds from sources external to Indonesia. This is considered unsustainable given how Indonesia is perceived globally to have been profited from four decades of unsustainable forest management. This donor funding support should be balanced by the national Government and private sector investment.

Learning from the failure of the majority of logging concessions in Indonesia, many parties still question the ability of a business entity that is generally profited oriented to implement and achieve the ecosystem restoration objectives. Each ERC management unit currently operating in Indonesia has its own management objectives. Based on its management objective and source of investment, Fiscal Policy Agency of Ministry of Finance classified the ERC management unit into four groups, included:

1. Conservation purposes group. This group was initiated by NGOs focusing on conservation issues, namely PT REKI, PT ABT and PT RHOI.

2. Business purposes group. This group was initiated by the private sector who seen ERC as an opportunity to develop business on environmental services and non-timber forest products. Members of this group include PT RRC, PT RMU, and PTEKL.

3. To create a company's green image. This g roup generally initiated by the private sector utilizing its corporate social 
and environmental responsibility funds. Members of this group include PT ASL and PT SBI.

4. To protect their assets. Members of this group apply for ERC permits to ensure that the ERC will generate benefits for the company's main business. This group includes PT GCN, PT GAN, PT SMN, and PT TBOUT which subsidiaries of RAPP (Riau Andalan Pulp and Paper) Group; PT KEN- a subsidiary of APP (Asia Pulp and Paper) Group; and PT SBI. Member of this group expressed objection to be grouped under this category because forest under ERC remains a state asset, and the implementation of ERC is to demonstrate the company's commitment to supporting biodiversity conservation.

Each ERC management unit had a different rational choice to apply and implement ecosystem restoration in the production forest. Each management unit made its management decisions based on the option that might generate or achieve the highest benefit and the lowest cost or risk for them (Arts, 2012). In this case, the highest benefits did not merely see from an economic perspective but also the achievement of an organization's vision, particularly for management units with conservation purposes and or the company's green image that would indirectly generate benefits for the companies. This is demonstrated by the fact that although the implementation of ERC remains very complex and required significant investments, in 2019, the MoEF received 72 ERC's application (MoEF, 2019)', and only 16 applications were approved. The majority of the application were rejected either because it could not meet the technical or administrative requirements, e.g., the proposed area overlaps with other land ownership claim or the management unit could not fulfill the financial requirement.

In the policy process, actors (either individual or an institution) with similar vision could establish a network, coalition, or alliance to improve their position and influence the process. Through the network, the agenda is strengthened and reinforced, and different opinions are suppressed. In certain policy domains, actor's networks are not limited to government agencies but may link up government agencies with the private sector, donor, and other actors from civil society, therefore producing a pluralist policy. The negotiation process between interest groups is at the center of the policy process (IDS, 2006). Actors involved in the ecosystem restoration policy process establish a network, namely the Ecosystem Restoration Working Group (ERWG) in 2016. The WG aims to create a good ecosystem restoration governance by improving the actor's understanding, knowledge, and innovation as well as through strengthening policy and regulation to support the implementation of ecosystem restoration (ERWG Secretariat). The establishment of ERWG was initiated by MoEF, who, in 2017, allocated budget for ecosystem restoration experts to provide technical assistance for the ERC management units.

ERWG's members include 16 ERC management units; ecosystem restoration experts who are a scientist from IPB University, Gajah Mada University, and Research and Development Agency of MoEF; representatives of Directorate General of Sustainable Production Forest
Management of MoEF; and NGOs that support the implementation of ERC namely Burung Indonesia, Wetland International Indonesia, Borneo Orangutan Survival Foundation, and Puter Foundation. The ERWG, which is an informal institution with voluntary-based membership, has a management body and a secretariat to support its activities. The member of the working group holds a monthly meeting to discuss policy development, progress, and challenges in the implementation of ecosystem restoration. It has a work plan funded jointly and voluntarily by its members. In the last two years, ERWG received funding support from the European Union?

Policy space of ecosystem restoration in the production forest Based on the content analysis of the ERC regulations (Table 2), this research identified the need to revised applicable regulation to support the implementation of ERC and facilitate different objectives of the ERC management unit currently operating in Indonesia. The policy change will only occur if there is policy space which can be identified through the examination of policy narrative, actors/network, and politic/interest (IDS, 2006; Sutton, 1999). Policy space referred to the extent to which a policymaker was restricted in decision-making by forces such as dominant narratives or actor networks. If there were strong pressures to adopt a particular strategy, the decision-maker might not have much room to consider a wider set of options (IDS, 2006; Sutton, 1999). The policy change was highly dependent on the ability of a particular discourse/narrative to create a new idea, which is accepted by a different actor and its network by using available policy space in the particular context, situation, and time (Kartodihardjo, 2008). The dominant narrative will reduce the policy space of the policymakers to thing about different approaches (Sutton, 1999). The ability of actors or actors network to affect policy change depends on the availability of recourses such as financial resources, information, public opinion, and legal authority. However, factors external to the policy system also affected policy changes (Kern \& Rogge, 2018).

In the context of ERC, each management unit has different management and business objectives, thereby requiring different management and governance system to achieve these objectives. The initial objective of ecosystem restoration in the production forest was to restore the productivity of the production forest. However, this concept has been developed into broader ecosystem-based forest management. It has been 12 years since the first ERC was issued, yet a large scale ERC that could be used as a model from which lessons can be drawn upon does not exist. All actors include MoEF, ERC management unit, scientists and practitioners are still looking for the right management type for ERC, and the learning process to implement the concept of ecosystem restoration in the production forest is ongoing. Although the actors have different rationale and objectives, they agreed on the narrative that the production forest had been destroyed and deforested. Therefore ecosystem restoration is urgently needed. To promote and strengthen the agenda related to the ecosystem restoration policy 
development, these actors established collaboration within ERWG. ERC policy process is incremental, complex, and dynamic. It is based on experimentation, learning from mistakes, and taking corrective measures (IDS, 2006).

Policy space to revise the ERC Regulation may emerge/be created in several forms, including conceptual space, bureaucratic space, invited space, popular space, and practical space. This study found that the dominant narrative of the production forest crisis proposed by the coalition of actors within ERWG has created several policy spaces to influence the development or revision of ecosystem restoration policy in the production forest, include:

- Conceptual spaces. The ecosystem restoration concept was introduced through various media, both international and national. ERC actors actively held and participated in the focus group discussion, workshop, and policy dialogue forum to introduce the concept of ecosystem restoration in the production forest and the progress in its implementation.

- Bureaucratic spaces. ERWG, whose members are representative of government agencies, private sector involving in ERC, NGOs, and scientists, serves as an avenue for policy dialogue. At the time when the ERC concept was introduced, the initiators had identified internal champions within MoEF who hold power to makes a strategic decision or policy discretion. Learning from this, ERWG may find other internal champions within MoEF to further influence the revision of current ERC policy to accommodate recent progress and challenges in the implementation of ecosystem restoration in the production forest in Indonesia.

- Invited spaces. MoEF is relatively open in providing space for consultation with other ERC actors. MoEF and ERWG have held several workshops and focus group discussions on ecosystem restoration in the production forest.

- Practical spaces. The implementation of ecosystem restoration in all ERC management units has generated rich data, information, knowledge, and lessons learned to inform necessary policy revisions. Unfortunately, systematic documentation of these aspects does not exist nationally.

Unfortunately, these policy spaces have not been effectively utilized by the ERC actors, not to mention it migh also be contested with other MoEF priorities. There is a clear need to expand existing policy space through broadening the network of actors, bringing in more influential figures to carry forward a stronger policy narrative to promote policy improvement.

Future policy of ecosystem restoration in the production forest Understanding ERC policy problems may lead to the next level of policy analysis, namely forecasting the future of ERC policy. However, we need to understand that any form of the forecast is prone to errors (Dunn, 2013). This forecast is based on informed judgments made by ERC's experts (conjecture) to minimize this risk,

Recognizing that the production forest in Indonesia is heavily degraded while the pace of forest recovery remains very slow, it is clear that ecosystem restoration is imperative. Currently, the total state forest area under ERC is only $21 \%$ of the GoI target. Significant effort is required to achieve the GoI's target. The financial capacity of ERC applicants or proponent or permit holders is one of the key factors to achieve this target ${ }^{8}$. Another key factor is policy revision. Particularly with regards to the provision of incentives be it in the form of ease in the development of a business that utilizes of non-timber forest products and environmental services from MoEF and fiscal incentives from Ministry of Finance in the form of Land and Building Tax Exemption; flexibility in the payment of License Fee; and reducing the amount of non-state tax incomes imposed on ERC. These incentives are expected to attract more investments in ERC. However, policy leadership is needed to make these things happen, as the discussion on the provision of incentives does not make significant progress as expected in the last two years ${ }^{9}$.

Ecosystem restoration on production forest was the responsibility of the Government, thereby it should not be implemented through a licensing mechanism but through the assignment. However, several ERC management units that consider this as a business license may disagree. Since they have paid for the licensing fee, an approach where ecosystem restoration is assigned and considered as Government's asset would be deemed unfavorable. To mitigate the complex licensing process and high initial investment cost, in the future, the ERC applicant may consider developing a join operation with Forest Management Unit (FMU) who is assigned by the Government to manage the majority of state forests in Indonesia ${ }^{10}$. FMU may mobilize potential public sector funding through government budget allocation to support ERC as well as donor and business funding (Davie \& Ridwandsyah, 2016). This is in line with the business reconfiguration in the production forest proposed by MoEF, which aims to develop the community-based business as well as to improve various commodity productions and multi-stakeholders business in order to achieve effective management of FMU (Agung et al., 2018).

\section{Conclusion}

ERC-related regulations that have been issued remain inadequate to support the implementation of ERC in Indonesia. Existing regulations remain heavily oriented towards timber-based utilization and have so far failed to accommodate various management objectives of the ERC management units operating in Indonesia. As a consequence, the implementation of ERC in Indonesia still faces numerous challenges in every step from the licensing process, implementation, and the performance evaluation of the management unit. The results of the policy process analysis highlighted there is a mismatch of rational expectations between MoEF and the ERC management units, which

${ }^{8}$ Interview with expert team of ERWG and scientist of Forestry Department of IPB University, on $18^{\text {th }}$ April 2019

${ }^{9}$ Interview with the Head of Sub-Directorate of ERC Performance Evaluation of MoEF, $2^{\text {nd }}$ Jully 2019

${ }^{10}$ Interview with Former Executive Director of Burung Indonesia, 26 ${ }^{\text {th }}$ April 2019 
presents another significant barrier to the achievement of ecosystem restoration objectives in Indonesia. Every actor involved in a policy process has its own consideration and rational choices and objectives, which are not only limited to profit-maximizing objective, but also to the achievement of biodiversity and habitat conservation as well as the need to establish or maintain a good reputation as a green private entity. The combination of ERC policy narratives with existing actors and networks of actors supporting the dominant policy narrative, have created various policy spaces for policy improvement, although has so far been poorly utilized by existing actors. Recognizing the state of Indonesia's production forest, ecosystem restoration policy is imperative. However, there is a clear need to improve the policy that should be able to facilitate the multiple business objectives of ERC management units currently operating in Indonesia.

\section{Recommendation}

Given the challenges and opportunities identified in this research, we recommend to revise the policy to overcome the "timber trap" in the ERC term, including to ensure the consistency of ecosystem restoration definition; to provide silviculture guideline as well as defined criteria and indicator for performance evaluation that are in line with the condition of the ecosystem and the business model of each management unit. ERC policy should provide clear guidance to the achievement of ecosystem restoration objectives that is to conserve biodiversity and to generate benefits for human wellbeing. Recognizing that the ecosystem restoration concept will continue to evolve over the years, the policy should provide flexibility and room for innovation for ERC management units. Therefore, it should avoid an overly rigid policy. For the past 12 years, the implementation of ecosystem restoration in the production forest has generated an immense amount of data, information, and lessons learned. This knowledge needs to be documented more systematically to serve as inputs for policy improvement and implementation in the future.

\section{Acknowledgment}

We would like to express our gratitude to USAIDPrestasi for the support for this research and to Ecosystem Restoration Working Group for allowing us participated in workshops and focus group discussions, provision of data and information, as well as the constructive discussion.

\section{References}

Agung, R, Rahayu, Y., Saputro, T., Tjandrakirana, R., Ramdhany, D., Wibawa, W., ..., \& Muttaqin, M. Z. (2018). Status hutan dan kehutanan Indonesia 2018. Jakarta: Kementerian Lingkungan Hidup dan Kehutanan.

Arts, B. (2012). Forests policy analysis and theory use: overview and trends. Journal of Forest Policy and Economic, 16, 7-13. https://doi.org/10.1016/j.forpol. 2010.12.003

[BPS] Badan Pusat Statistik. (2016). Publikasi statistik perusahaan hak pengusahaan hutan. Jakarta: Badan
Pusat Statistik. Retrieved from https://www.bps.go.id/ linkTableDinamis/view/id/1115

Brancalion, P. H. S., Meli, P., Tymus, J. R. C., Lenti, F. E. B., Benini, R. M., Silva, A. P. M., ..., \& Holl, K. D. (2019). What makes ecosystem restoration expensive? A systematic cost assessment of projects in Brazil. Biological Conservation, 240, 108274. https://doi.org/ 10.1016/j.biocon.2019.108274

Brockhaus, M., Obidzinski, K., Dermawan, A., Laumonier, Y., \& Luttrell, C. (2012). An overview of forest and land allocation policies in Indonesia: Is the current framework sufficient to meet the needs of REDD+? Forest Policy and Economics, 18, 30-37. https://doi.org/10.1016/ j.forpol.2011.09.004

Buergin, R. (2016). Ecosystem restoration concession in Indonesia: Conflict and discourses. Critical Asian studies, 48(2), 278-301. https://doi.org/10.1080/ 14672715.2016.1164017

Center of Forestry Planning and Statistic. (2009). Indonesia forestry outlook study. Bangkok: Food and Agriculture Organization of the United Nations Regional Office for Asia and the Pacific. Retrieved from http://www.fao.org/ 3/am608e/am608e00.pdf

Covington, W. W., Niering, W. A,. Starkey, E., \& Walker, J. (1999). Ecosystem restoration and management: Scientifict principles and concept. In Ecological Stewardship: A common Reference for Ecosystem Management Reference (pp. 599-617). Amsterdam: Elsevier. Retrieved from: https://www.srs.fs.usda.gov/ pubs/misc/misc_covington.pdf

[CBD] Convention on Biological Diversity. (2016). Ecosystem restoration: Short-term action plan. CBD / C OP/DEC/XIII/ 5. Retrived from https://www.cbd.int/doc/decisions/cop-13/cop-13-dec05-en.pdf

Davie, J., \& Ridwansyah, M. (2016). The Hutan Harapan lesson learnt review: Final report. Jakarta: DANIDA.

Directorate General of Sustainable Production Forest Management. (2017). Data release Ditjen PHPL. Jakarta: Directorate General of Sustainable Production Forest Management, Ministry of Environment and Forestry. Retrieved from http://phpl.menlhk.go.id

Dunn, W. N. (2013). Public policy analysis: An introduction (2nd ed.). Yogyakarta: Gajah Mada University Press.

Gann, G. D., McDonald, T., Walder, B., Aronson, J., Nelson, C. R., Jonson, J., ..., \& Dixon, K. W. (2019). International principles and standards for the practice of ecological restoration (2nd ed.). Washington: Wiley Periodicals, Inc. Retrieved from https://cdn.ymaws.com/ www.ser.org/resource/resmgr/docs/ser_international_st andards_.pdf.https://doi.org/10.1111/rec.13035 
Gaveau, D. L. A., Kshatriya, M., Sheil, D., Sloan, S., Molidena, E., Wijaya, A., ..., \& Meijaard, E. (2013). Reconciling forest conservation and logging in Indonesian Borneo. PLoS ONE, 8(8), e69887. https://doi.org/10.1371/journal.pone.0069887

Hall, D. M., \& Steiner, R. (2020). Policy content analysis: Qualitative method for analyzing sub-national insect pollinator legislation. MethodsX, 7, 100787. https://doi.org/10.1016/j.mex.2020.100787

Hsieh, H. F., \& Shannon, S. E. (2005). Three approaches to qualitative content analysis. Qualitative Health Research, 15(9), 1277-1288. https://doi.org/10.1177 \%2F1049732305276687

Howland, D., Becker, M. L. \& Prelli, L. J. (2006). Merging content analysis and the policy sciences: A system to discern policy-specific trends from news media reports. Policy Sciences, 39, 205-231. https://doi.org/10.1007/ s11077-006-9016-5

[IDS] Institute of Development Studies. (2006). Understanding policy process: A review of IDS research on the environment. Brighton: University of Sussex.

Kartodihardjo, H. (2008). Discourses and actors in the forest policy formulation: Problems of rational framework. Jurnal Manajemen Hutan Tropika, 14(1), 19-27.

Kartodihardjo, H., Nagara, G., \& Situmorang, A. W. (2015). Transaction cost of forest utilization licenses: Institutional issues. Jurnal Manajemen Hutan Tropika, 21(3), 184-191.https://doi.org/10.7226/jtfm.21.3.184

Kartodihardjo, H., (2017). Dibalik krisis ekosistem: Pemikiran tentang kehutanan dan lingkungan hidup. Jakarta: LP3ES (Lembaga Penelitian, Pendidikan, dan Penerangan Ekonomi dan Sosial).

Kern, F., \& Rogge, K. S. (2018). Harnessing theories of the policy process for analysing the politics of sustainability transitions: A critical survey. Environmental Innovation and Societal Transition, 27, 102-117. https://doi.org/10. 1016/j.eist.2017.11.001

Margono, B. A., Turubanova, S., Zhuravleva, I., Potapov, P., Tyukavina, A., Baccini, A., ..., \& Hansen, M. C. (2012). Mapping and monitoring deforestation and forest degradation in Sumatra (Indonesia) using Landsat time series datasets from 1990 to 2010. Environmental Research Letter, 7, 034010. https://doi.org/10.1088/ $1748-9326 / 7 / 3 / 034010$

[MoF] Ministry of Forestry. (2004). Minister of Forestry Regulation Number SK.159/Menhut-II/2004 concerning the Ecosystem Restoration on the Production Forest. Jakarta: Ministry of Forestry.

[MoF] Ministry of Forestry. (2010). Minister of Forestry Regulation Number P.08/Menhut-II/2010 concerning the Strategic Plan of Ministry of Forestry Period 2010-2014.
Jakarta: Ministry of Forestry.

[MoF] Ministry of Forestry. (2008). Minister of Forestry Regulation Number P.61/Menhut-II/2008 concerning Provision and Procedures for the Granting of Timber Utilization Business Permit for Ecosystem Restoration in the Natural Production Forest through Application. Jakarta. Ministry of Forestry

[MoF] Ministry of Forestry. (2014). Minister of Forestry Regulation Number P.64/Menhut-II/2014 concerning the Application of Silviculture in the Areal of Timber Utilization Permit for Ecosystem Restoration in the Production Forest. Jakarta. Ministry of Foresty.

[MoEF] Ministry of Environment and Forestry. (2015). Minister of Environment and Forestry Regulation Number 39/Menlhk-Setjen/2015 on the Strategic Plan of Ministry of Environment and Forestry Period 2015-2019. Jakarta: Ministry of Environment and Forestry.

[MoEF] Ministry of Environment and Forestry. (2017). Statistic of environment and forestry 2017. Jakarta: Ministry of Environment and Forestry.

[MoEF] Ministry of Environment and Forestry. (2018). Roadmap of management of ecosystem restoration in production forest. Jakarta: Directorate of Environmental Services and Non-Timber Forest Production Business in the Production Forest, Directorate General of Sustainable Production Forest Management, Ministry of Environment and Forestry.

Myers-Madeira, E., Sills, E., Brockhaus, M., Verchot, L., \& Kanninen, L. (2010). What is a REDD+ pilot? A preliminary typology based on early actions in Indonesia. CIFOR Infobrief No 26. Bogor: CIFOR.

Nadefier, M., Goli, H., \& Ghaljaie, F. (2017). Snowball sampling: A purposeful method of sampling in qualitative research. Strides in Development of Medical Education Journal, 14(3), e67670. https://doi.org/10. 5812/sdme. 67670

Purba, C. P., Nanggara, S. G., Ratriyono, M., Apriani, I., Rosalina, L., Sari, NA., \& Meridian, A. H. (2014). The state of Indonesia forest period 2009-2013. Bogor: Forest Watch Indonesia.

Rahmawati, A. (2013). An economic analysis of ecosystem restoration concession policy in Indonesia: A new strategy for sustainable forest management? International Journal of Green Economics, 7(1), 56-57.

Roe, E. M. (1991). Development narratives, or making the best of blueprint development. World Development, 19(4), 287-300.

Silalahi, M., \& Erwin, D. (2015). Collaborative conflict management on ecosystem restoration concession: Lessons learnt from Harapan Rainforest Jambi-South 
Sumatra-Indonesia. Forest Research, 4, 134. https://doi. org/10.4172/21689776.1000134

Silalahi, M., \& Utomo, A. B. (2014). Ecosystem restoration concession (ERC) development in Indonesia. Presented at A Capacity Building Workshop for South East Asia on Ecosystem Conservation and Restoration to Support Achievement of Aichi Biodiversity Targets. Burung Indonesia, Jambi, April 28-May 2.

Sitompul, A., Linkie, M., Gunaryadi, D., Purastuti, E., \& Budiman, A. (2011). Ecosystem restoration concession: A new strategy for conserving elephant habitat in Sumatra? Gajah, 34, 26-31.

Sutton, R. (1999). The policy process: An overview. London: Chameleon Press Ltd.

Susanti, A., \& Maryudi, A. (2016). Development narratives, notion of forest crisis, and book of oil palm plantation in
Indonesia. Forest Policy and Economics, 73, 130-139. https://doi.org/10.1016/j.forpol.2016.09.009

Tsujino, R., Yumoto, T., Kitamura, S., Djamaluddin I., \& Darnaedi, D. (2016). History of forest loss and degradation in Indonesia. Land Use Policy, 57, 335-347. https://doi.org/10.1016/j.landusepol.2016.05.034

Widianingsih, N. N., David, W., Pouliout, M., \& Theilade, I. (2019). Land use, income, and ethnic diversity in the margins of Hutan Harapan - A rainforest restoration concession in Jambi and South Sumatra, Indonesia. Land Use Policy, 86, 268-279. https://doi.org/10.1016/ j.landusepol.2019.05.006

World Bank. (2006). Sustaining Indonesia's forest. Jakarta: World Bank. Retrieved from http://siteresources. worldbank.org/INTINDONESIA/Resources/Publicatio n/280016-1152870963030/IDForest Strategy.pdf?resour ceurlname=IDForestStrategy.pdf 